\title{
From Bullettino della Società Botanica Italiana to Italian Botanist, passing through Informatore Botanico Italiano. A 128 years-long story
}

\author{
Lorenzo Peruzzi', Consolata Siniscalco ${ }^{2}$
}

I Dipartimento di Biologia, Università di Pisa, Via Derna 1, 56126 Pisa, Italy 2 Dipartimento di Scienze della Vita e Biologia dei Sistemi, Viale Mattioli 25, 10125 Torino, Italy

Corresponding author: Lorenzo Peruzzi (lorenzo.peruzzi@unipi.it)

Received 5 April 2016 | Accepted 20 April 2016 | Published 11 May 2016

Citation: Peruzzi L, Siniscalco C (2016) From Bullettino della Società Botanica Italiana to Italian Botanist, passing through Informatore Botanico Italiano. A 128 years-long story. Italian Botanist 1: 1-4. doi: 10.3897/italianbotanist.1.8646

In 1888, concomitant with the foundation of the Italian Botanical Society, a section called Bullettino della Società Botanica Italiana appeared in the last pages of each issue of volume 20 of the Nuovo Giornale Botanico Italiano (currently the international journal Plant Biosystems). Since the very beginning, this was the place where the formal proceedings of the Society and a summary of the scientific contents of the Society meetings were published. Since then, albeit without an autonomous numbering, the bulletin was regularly published several times a year. From 1894 and until 1926, along with the first volume of the new series of Nuovo Giornale Botanico Italiano, the bulletin started to appear only once a year, at the end of the last issue. Between 1927 and 1961 its name was changed to Rendiconti delle Sedute e Brevi Comunicazioni, but its publication continued. Further details on these intricate and puzzling first decades of the bulletin can be found in Maugini (1988). When, in 1962, the journal changed its name again to Giornale Botanico Italiano, the bulletin also changed its name back to Bollettino della Società Botanica Italiana, and remained as such up to 1968. During the Congress of the Italian Botanical Society held in Piacenza in September 1968, the General Assembly voted for a full separation of the bulletin from Giornale Botanico Italiano, so that it became an independent publication named Informatore Botanico Italiano (Pignatti et al. 1969; Fig. 1A). The first issue was published in April 1969. For about three decades, the journal consisted of three issues per year and, later, of only two issues with occasional supplements.

Copyright Lorenzo Peruzzi, Consolata Siniscalco. This is an open access article distributed under the terms of the Creative Commons Attribution License (CC BY 4.0), which permits unrestricted use, distribution, and reproduction in any medium, provided the original author and source are credited. 

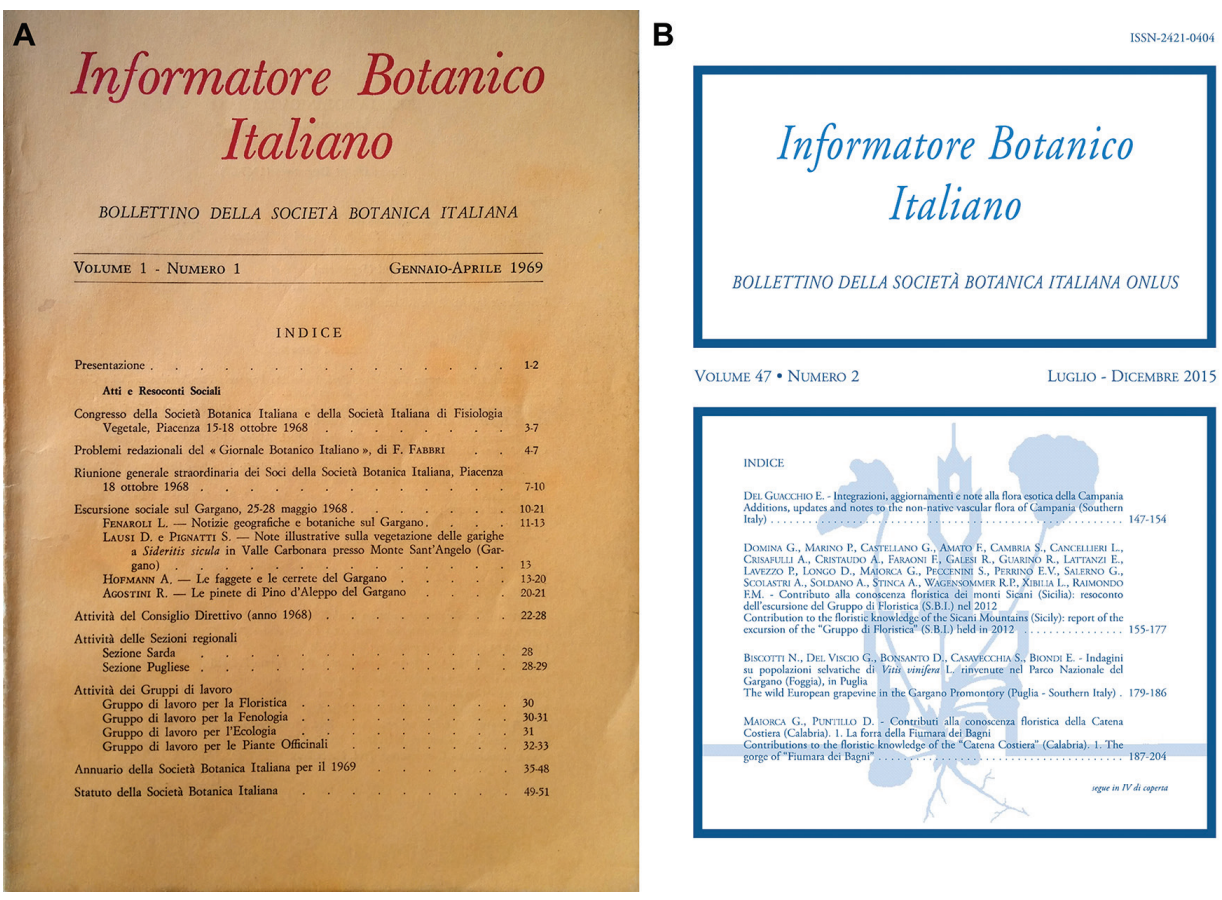

Figure I. Front covers of the first issue of the "Informatore Botanico Italiano", published in 1969 (A) and of the last issue of the "Informatore Botanico Italiano", published in 2015 (B).

The initial focus of this journal was the same as that of the earlier bulletins, i.e., to publish the administrative and scientific proceedings of the Society, the yearbook of the members, but also ad hoc submitted scientific notes (for a synthesis of the topics published in its first ten years, see Meletti 1981). The year 1988 marked the centenary of the Italian Botanical Society. For the occasion, a monumental 331page contribution appeared in the journal (Pedrotti 1990), while, in 1998, an Italian translation of the International Code of Botanical Nomenclature (Tokyo code) was published (Mazzola 1998). Over the years, scientific contributions began to prevail over proceedings, and several important scientific columns were introduced. These were Numeri Cromosomici per la Flora Italiana, reporting cytotaxonomic contributions on the Italian flora, in 1970 (for more information see Bedini et al. 2012); Segnalazioni Floristiche Italiane, hosting relevant new floristic records for Italy, in 1978 (for a synthesis and comments of the records published up to 1995, see Nepi 1997); Notulae Cryptogamicae, focused on algae, bryophytes, fungi and lichens, in 2010; Schede per una Lista Rossa della Flora vascolare e crittogamica italiana, concerning the IUCN protocol assessment of the Italian flora, in 2011. After publication of the checklist of the Italian vascular flora by Conti et al. (2005), the column Segnalazioni Floristiche Italiane became Notulae alla checklist della flora vascolare italiana and, after the publication of the inventory of the non-native flora of Italy by Celesti-Grapow et al. (2009), it hosted a sub-column concerning the record of alien plant species in 
Italy, which eventually acquired the status of an independent column (Notulae alla flora esotica d'Italia) in 2015.

In recent years, an enormous number of floristic studies have been published, the major ones concerning large portions of the Italian territory, such as the Cilento (Moggi 2002), Lazio (Anzalone et al. 2010), Calabria (Bernardo et al. 2011), EmiliaRomagna (Alessandrini 2012), and the Province of Lucca (Pierini and Peruzzi 2014). Important taxonomic contributions have also appeared in the journal, such as those on Festuca L. and allied genera (Foggi et al. 2007, 2010), Alchemilla L. (Fröhner et al. 2012), and Polygala L. (Arrigoni 2014).

Since 1969, a total of 47 volumes and 117 issues of Informatore Botanico Italiano have been published (Fig. 1B). At the end of 2015, the Directive Council of the Italian Botanical Society decided to make some editorial changes. The administrative and scientific proceedings of the Society and other general information (meetings, exhibits, book reviews, excursions, etc.) will now appear in Notiziario della Società Botanica Itali$a n a$, an online newsletter in Italian. Meanwhile, in order to boost the scientific value and international visibility of Informatore Botanico Italiano, the choice has been to shift to an online, open access journal written in English and called Italian Botanist. In order to disseminate its contents more efficiently, it is published using the advanced technologies offered by the Pensoft platform. The journal is peer-reviewed, and hosts original research articles covering all fields of botany in its broader sense, from molecular to ecosystem levels, including mycology. The geographical coverage of Italian Botanist is specially focused on the Italian territory, but studies from other areas are also welcome.

Each issue will contain the following scientific columns:

Chromosome numbers for the Italian flora

Global and Regional IUCN Red List Assessments

Notulae to the Italian flora of algae, bryophytes, fungi and lichens

Notulae to the Italian native vascular flora

Notulae to the Italian alien vascular flora

Our hope is that this renewed version of the journal will serve the Italian - and foreign - botanical community more efficiently and provide readers worldwide with an easier access to knowledge concerning the Italian flora.

Lorenzo Peruzzi, Editor-in-Chief of Italian Botanist Maria Consolata Siniscalco, President of the Italian Botanical Society

\section{References}

Alessandrini A (Ed.) (2012) Contributi alla conoscenza della flora regionale realizzati con il sostegno dell'Istituto Beni Culturali della Regione Emilia-Romagna. Informatore Botanico Italiano 44(suppl. 1): 3-86. 
Anzalone B, Iberite M, Lattanzi E (2010) La Flora vascolare del Lazio. Informatore Botanico Italiano 42(1): 187-317.

Arrigoni PV (2014) Revisione tassonomica e corologica del genere Polygala in Italia. Informatore Botanico Italiano 46(2): 235-263.

Bedini G, Garbari F, Peruzzi L (2012) Karyological knowledge of Italian vascular flora as inferred by the analysis of "Chrobase.it". Plant Biosystems 146(4): 889-899. doi: 10.1080/11263504.2011.611182

Bernardo L, Passalacqua NG, Peruzzi L (Eds) (2011) Flora vascolare della Calabria - Prodromo. Informatore Botanico Italiano 43(2): 185-332.

Celesti-Grapow L, Alessandrini A, Arrigoni PV, Banfi E, Bernardo L, Bovio M, Brundu G, Cagiotti MR, Camarda I, Carli E, Conti F, Fascetti S, Galasso G, Gubellini L, La Valva V, Lucchese F, Marchiori S, Mazzola P, Peccenini S, Poldini L, Pretto F, Prosser F, Siniscalco C, Villani MC, Viegi L, Wilhalm T, Blasi C (2009) Inventory of the non-native flora of Italy. Plant Biosystems 143(2): 386-430. doi: 10.1080/11263500902722824

Conti F, Abbate G, Alessandrini A, Blasi C (Eds) (2005) An Annotated Checklist of the Italian Vascular Flora. Palombi Editori, Roma, 428 pp.

Foggi B, Parolo G, Rossi G, Ardenghi NMG, Quercioli C (2010) Il genere Festuca e i generi affini per una flora critica dell'Italia. II. I generi Leucopoa e Drymochloa (Poaceae). Informatore Botanico Italiano 42(1): 335-361.

Foggi B, Rossi G, Parolo G, Wallossek C (2007) Il genere Festuca e i generi affini per la nuova "Flora critica d'Italia". I. Festuca sect. Eckia Willk. in Italia. Informatore Botanico Italiano 39(1): 199-232.

Fröhner SE, Bona E, Federici G, Martini F (2012) Contributo alla conoscenza del gen. Alchemilla sulle Alpi Italiane: Alpi Retiche Meridionali, Prealpi Lombarde Centrali e Orientali. Informatore Botanico Italiano 44(1): 3-73.

Mazzola P (Ed.) (1998) Codice internazionale di nomenclatura botanica. Informatore Botanico Italiano 29(1)[1997]: 1-133.

Maugini A (1988) La Società Botanica Italiana: vicende storiche. In: Pedrotti F (Ed.) 100 anni di ricerche botaniche in Italia (1888-1988). Società Botanica Italiana, Biemmegraf, Piediripa di Macerata, 1-84.

Meletti P (1981) I 10 anni dell'Informatore Botanico Italiano. Informatore Botanico Italiano 11(3)[1979]: 285-288.

Moggi G (2002) Catalogo della flora del Cilento. Repertorio delle piante vascolari finora segnalate e problemi sistematici connessi. Informatore Botanico Italiano 33(suppl. 3)[2001]: 1-116.

Nepi C (1997) Le Segnalazioni Floristiche Italiane dal 1978 al 1995: indici e commenti. Informatore Botanico Italiano 28(2)[1996]: 183-249.

Pedrotti F (Ed.) (1990) Atti del Congresso celebrativo del I centenario (83 Congresso Sociale). Firenze, 8-12 gennaio 1988. Informatore Botanico Italiano 20(1)[1988]: 1-331.

Pierini B, Peruzzi L (2014) Prodromo della flora vascolare della Provincia di Lucca (Toscana nordoccidentale). Informatore Botanico Italiano 46(1): 3-16. [electronic appendix, 500 pp.]

Pignatti S, Sarfatti G, Fabbri F (1969) Presentazione. Informatore Botanico Italiano 1(1): 1-2. 